How to Cite

Sukarsih, N. N. T. (2019). English terms of address in the bible and their equivalents in Balinese: a translation

study. International Journal of Humanities, Literature \& Arts, 2(1), 1-8. https://doi.org/10.31295/ijhla.v2n1.54

\title{
English Terms of Address in the Bible and Their Equivalents in Balinese: A Translation Study
}

\author{
Ni Nyoman Tri Sukarsih \\ Universitas Dhyana Pura, Denpasar, Indonesia \\ Email: trisukarsih_dp@yahoo.com
}

\begin{abstract}
Bible translation always poses problems, both linguistic and non-linguistic. The work in this study deals with: the problem of translating terms of address in the Bible of English (SL) into Balinese (TL). As there are several versions of the Bible, the one selected for this study is Today's English Versions which is translated in Balinese by LAI. Differences in the system of terms of address in English and Balinese become problematic in selecting the appropriate pronoun or noun for terms of address; and this is made complicated by the fact that Balinese has two varieties of language use, i.e. common and high.
\end{abstract}

Keywords---common, high, term of address.

\section{Introduction}

This study investigates the strategies adopted in the translation of the terms of address related to behavior and the degree to which these strategies are effective in conveying the rich nuances of English terms of address in the Bible and their equivalents in Balinese. It was found that both the source language (SL)-oriented and target language (TL)oriented approaches were utilized. However, the translations of all the texts adhered are more extensively to the principles of the TL-oriented translation approach. Those meanings and implications were found to be essential for an adequate understanding of the original texts. In rare cases, however, where the translators adopted the SL-oriented strategy to transfer the linguistic and Christian tradition of the original terms, they were successful in conveying the meanings and implication intended by the original writers through their use of the terms, thus helping the target reader develop a similar understanding of the target texts as the original readers would have of the source texts. The study raised the need for translators of English-Balinese literary texts, especially in treating terms of address and reference, to pay attention to the linguistic and Christian tradition of the source texts.

The purpose of translation is to transfer the meaning of the source language text into the target language text which is done from the form of the first language to the form of the second language of semantic structure. It is only the form changed, while meaning which is being transferred must be held constantly. To do an effective translation one must discover the meaning of the source language and use target language which expresses this meaning in a natural way (Larson, 1998). Based on Larson's statements, it appears that understanding meanings of words in a text becomes vital in translation. A translator often entails the problem of optional decision which determines the degree of word equivalent of SL and TL in a translation. Without understanding what the word in a text to be translated means, the meaning would be hopelessly lost.

Based on the background of the study above, the problem can be formulated in this study are: (1) What are the English terms of address related to behavior and their equivalents in Balinese on Cakepan Suci? (2) How are the translation strategies adopted in the translation of terms of address?.

Concept and Theoretical Frame Work

This study is carried out a few concepts in order to take into consideration including the following: the target language translator approach, the source language translation approach, the Balinese terms of address.

ISSN 2632-9441

Received Jan 20, 2019 / Accepted Jun 18, 2019 / Published Jul 05, 2019 


\section{The Target Language Translation Approach}

The concern with fluency and naturalness in TL-oriented translation means that it allows alteration or adaptations of the SL items, such as "shifting word order, using verbs in place of nouns, and substituting nouns for pronouns" (Nida 1964). In other words, in this type of translation, the translator seeks dynamic equivalence (also referred to as "dynamic equivalence" translation (Nida 1964). Domestication also permits adjustments to "special literary forms," "semantically exocentric expressions of linguistic forms. If the source text contains linguistic and cultural elements alien to the target language and culture, they are likely to be avoided in the translation (Bassnett, 1997).

One way of defining a dynamic equivalent is to describe it as "the closest natural equivalent to the source language message." This type of definition contains three essential terms: (1) equivalent, which points towards the source language message, (2) natural, which points toward the receptor language, and (3) closest, which binds the two orientations together on the basis of the highest degree of approximation. Basically, the word natural is applicable to three areas of the communication process; for a natural rendering must fit (1) the receptor language and culture as a whole, (2) the context of the particular message, and (3) the receptor-language audience.

\section{The Source Language Translation Approach}

The source language-oriented method puts "an ethnic deviant pressure on (target-language cultural) values to register the linguistic and cultural difference of the foreign text, sending the (target) reader abroad" (Venuti, 1995). Using this method, the translator is expected to preserve the foreign identity of the source text by seeking the "purely 'formal' replacement of one word or phrase in the SL by another in the TL" (Hatim \& Munday, 2004). Nida refers to this type of translation as "gloss translation, "which is" designed to permit the (TL) reader to identify himself as fully as possible with a person in the source-language context, and to understand as much as he can of the customs, manner of thought, and means of expression" and which may "require numerous footnotes in order to make the text fully comprehensible" (Nida, 1964). Such footnotes can disrupt the flow of the text. For this reason, the foreignizing approach is not commonly utilized. However, formal-equivalence translations are useful in situations where essential elements of the narrative would be lost by the use of the dynamic-equivalence approach (Subiyanto, 2016); Suryasa et al., 2019).

\section{The Balinese Term of Address}

Forms of address are words or phrases used for addressing (Braun 1988). The use of forms of address varies form one language to another. In Mandarin Chinese (Wu, 1986) for example, kinship terms can be used to address both acquaintance and stranger. However, in Balinese kinship terms can only be used to address are complicated. The selection of the address norms is determined by social status and other social variables such as age, sex, generation and so on. Wangsa system is a predominant factor for social status in Balinese society. This section attempts to investigate the use of Balinese terms of address in different social contexts. The type of forms of the address will be described in terms of pronominal and nominal forms. Subsequently, the use of terms of address with nonreciprocal use of address variants signals status differences, while reciprocal use of address variants signals either mutual distance or intimacy regardless of status differences.

The use Balinese terms of address and in actual communication is extremely intricate. Both the use and the meanings of Balinese person-referring forms are saliently and inextricably linked to the birth sequence marker, caste in the relations between the addresser and addressee.

\section{Theoretical framework}

This study applies the theory Terms of address from Braun (1988); Brown \& Gilman (1960), talking about Pronominal Forms of Balinese Address System.

\section{Term of Address}

Braun (1988), stated that terms of address comprise also address inversion which means a special pattern of nominal address. Address behavior is the way individual speakers or groups of speakers use the repertory of address variants available to them. From a sociolinguistic point of view, address behavior is meaningful whenever speakers have to choose between several variants, all of which are grammatically correct in a given conversational context. Extralinguistic factors then determine the selection of grammatically interchangeable forms. The system of address comprises the totality of available forms and their interrelations in one language. In some languages, there is only one pronoun of address for an individual addressee (English). It goes without saying that the existence of several variants makes nonreciprocal usage easier and more frequent and allows a more detailed encoding of differences in age, sex, social, or occupational status. Moreover, cultural norms and values can be reflected in an address system. 
Reciprocity and symmetry; Address is reciprocal when two speakers exchange the same form of address (or equivalent ones). Correspondingly, the address is non-reciprocal when the forms used by the two speakers are not equivalent. When different forms are used, the address relationship is asymmetrical.

\section{Pronominal Forms of Balinese Address System}

Balinese applies systems of pronouns and possesses two or more variants. In the Western literature on pronouns, Brown \& Gilman (1960), described two variants; T and V.T refer to a familiar or intimate relationship between the speaker and addressee, while $\mathrm{V}$ designates a polite or distant form.

Table 1

The terminology of Balinese pronoun variant according to Brown and Gilman's concept

\begin{tabular}{|c|c|c|c|c|c|}
\hline \multirow{2}{*}{$\begin{array}{l}\text { Personal } \\
\text { pronouns }\end{array}$} & \multicolumn{4}{|c|}{ Variants } & \multirow{2}{*}{ English Gloss } \\
\hline & $\mathrm{T} 1$ & $\mathrm{~T} 2$ & V1 & V2 & \\
\hline $1^{\text {st }}$ Pronouns & Kai & $\begin{array}{l}\text { Icang } \\
\text { Cang } \\
\text { Waké }\end{array}$ & Tiang & Titiang for humble & “I” \\
\hline $2^{\text {nd }}$ Pronouns & Iba, nani & $\begin{array}{c}\text { Cai }(M) \\
\text { Nyai }(F m)\end{array}$ & Ragane, jero & $\begin{array}{c}\text { Cokeridéwa ratu, } \\
\text { atau }\end{array}$ & ‘you’ \\
\hline $3^{\text {rd }}$ Pronouns & $\begin{array}{l}\text { Poloné } \\
\text { ia }\end{array}$ & Ia & dané & $\begin{array}{l}\text { Ida for refined, } \\
\text { ipun for humble }\end{array}$ & 's/he' \\
\hline
\end{tabular}

The application of this concept is determined by the "power semantic" and "solidarity semantic" (Brown \& Gilman 1960). The former is a relationship between the speaker and address of different status which may be asymmetrical. For example, A gives $\mathrm{V}$ to $\mathrm{B}$ and receives $\mathrm{T}$. the letter is a relationship between speaker and addressee of equal status. It is also called an asymmetrical relationship. For example, A gives $\mathrm{T}$ to $\mathrm{B}$ and receives $\mathrm{T}$ or A gives $\mathrm{V}$ to $\mathrm{B}$ and receives V (Brown \& Gilman, 1960). These concepts are especially useful in a language with a contrast of two pronoun variants. Balinese, however, has more than two variants, the terminology might be extended to T, V1, V2, or in fact, it may be extended to T1/T2 and V1/V2, where the connotation of a V pronoun is very depended on the status of other participants (Braun, 1988).

\section{Terms of Address Related to Divinity}

The word "LORD" is used constantly in the Old Testament, and it does, of course, refer to Johovah or Yahweh, and to the Christian God of the New Testament. But a quick reading of the theological texts of the religions shows that the same words such as: LORD, King, Almighty, All-seeing, All-knowing, Lord God do crop up throughout.

Once three has a concept of a monotheistic God, these terms are inevitably used to address the idea of a supreme being who is superior to man.

In simple terms, any translation must convey the idea of a supreme being. Therefore it matters if this is done by the use of "God" defined as King, Soverign ruler or in Balinese Ida Sang Hyang Widi Wasa. The data are presented as follows:

\section{SL}

(a) The Lord All-Powerful has made this promise: Everything I've planned will happen just as I said (Izaiah 14:24) (b) .... Abraham answered, "Here I am, LORD” (Genesis 22:1).

(c) Well then, The Lord himself will give you a sign: a young woman who is pregnant will have a son and will name him "Immanuel". (Isaiah 7: 14)
Ida Sang Hyang Widi Wasa sane Maha Kuasa sampung ngwedar sumpah sapuniki: Apa ane suba rencanayang ulun ento lakar kasidan. Apa ane lakar laksanyang ulun ento lakar dadi (Nadi Yesaya $14: 24)$

\section{TL}

....Dane Abraham tumuli matur "Ingguh titiang, Ratu Panembahan. (Purwakaning Dadi 22:1)

Sujatinipun, Ida Sang Hyang Widi Wasa ngaga pacang mapaica cihna ring palunggung iratu, inggih punika wenten anak daa genten jaga mobot tur pacang ngembasang putra lanang, tur rarene punika 
jaga kaparabin "Imanuel" (Nabi Yesaya 7:14).

(d) Announce to the nations, "The Lord is Baosanja ring sakancan bangsane, sapuniki, "Ida King! The world stands film, never to Sang Hyang Widi Wasa punika maraga Sang Prabu. be shaken, and $\mathrm{He}$ will judge its Jagate sampun kagenahang saha kukuh bakuh ring people with fairness." (Psalm 96:10) genah nyane tur nenten mrasidayang makisid. Ida jaga nepasin bangsa-bangsane antuk keadilan". (Kidung $96: 10$ )

(e) Our Lord, You have made Your nation stronger! Because of You its people are glad and celebrate like workers at harvest time or like soldiers dividing up what they have taken. (Isaiah 9:3)

Duh Ratu Sang Hyang Widi Wasa, sampun maicayang kaliangan sane ageng ring ipun. Palungguh I Ratu sampun ngawinang ipun nemu bagia. Ipun girang ring sajeroning paindikan sane sampun kardi palungguh Ratu. Girang ipune tan bina sekadi girang ipune rikala ngampug gandum arta jejerahan. (Nabi Yesaya 9:3).

(f) A Child is born to us! A Son is given to us! And he will be our ruler. He will be called, "Wonderful Counselor". "Mighty God", "Eternal Father", "Prince of Peace". (Isaiah 9:6).

Wenten satunggaling rare sampun embas pabuat iraga, satunggaling rare lalang sampun kapaicang ring iraga! Ida pacang dadis pamrentah iragane, Ida pacang kaparabin : "Juru Pitutur Wicaksana", Ida Sang Hyang Widi Wasa sane Maha Kuasa", "Sang Aji Aane Langgeng", "Ratu Damene". (Nabi Yesaya 9:6).

(g) His royal power will continue to grow: Kekuasaan kaprabon idane sayan mawuwuhHis kingdom will always be at peace. wuwuh tur nglantur kaprabon idane pacang tansah $\mathrm{He}$ will rule as King David's kerta raharja. Ida pacang dados prabu ngentosin Ida successor, bring his power on right Sang Prabu Daud santukan ida ngrajegang and justice, from now until the end of kekuasaan idane sajeroning kapatutan lan kadilan, time. The LORD Almighty is ngawit saking mangkin kantos rauh kawekasan. Ida determined to do all this (Isaiah 9:7). Sang Hyang Widi Wasa Sane Maha Kuasa sampun mastiang pacang ngamargiang sekancan paindikane puniki (Nabi Yesaya 9:7).

(h) Listen to us O, Shepherd of Israel; Duh ratu Sang Pangangon wong Israele pirengangja hear us, leader of your flock, seated on atur titiange, Duh Ratu sane pamimpin ingon-ingin your throne above the winged druene, pirengangja pinunas titiange! (Kidung creatures (Psalms 80:1). 80:1).

(i) Your word is a lamp to guide me and a Sabdan Palungguh Iratune minakadi suluh buat light for my path (Psalms 119:105).

nuntun titiang, samaliha maka dados galang pabuat margin titiange. (Kidung $119: 105$ )

(j) So also will be the word that I speak it Nah aketo masih sabdan ane sabdayang ulun ia will not fail to do what I plan for it; it lakar sida karya ngelaksayang sawatek ane will do everything I send it to do rencanayang Ulun (Nabi Yesaya 55:11).

(Isaiah 55:11)

(k) Before the world was created, the Sadurung jagate puniki kawentenang antuk Ida word already existed. He was with Sang Hyang Widi Wasa, Sang Sabda sampun God, and the word was God (John wenten. Sang Sabda punika sinarengan ring Ida $1: 1)$. 
(l) His name is; "The Word of God" (Revelation 19:13).

Ida madue parab sane matulis ring ragan Idane sane ten wenten anak sane uning sejawaning Ida (Wahyu 19:13).

(m) The terms related to Ideas of God the first man was named Adam, and the scriptures tell us that he was a living person, But Jesus who may be called the Last Adam, is a life-giving spirit (I Corinthians 15:45).

(n) I am the one called Amen! I am the faithful and true witness and the Source of God's Creation. Listen to what I Say (Revelation 3:14).

Sakadi sane sampun jasuratang ring Cakupan Sucine : "Manusane sane pangawit inggih punika Adam, dane kakardi kadadosang jadma sane urip". Nanging Adan sane wekasan punika maraga Roh Sane nguripang (I Korintus 15:45).

Ene subda uli Sang Maraga Mamin, Saksi ane satia tuu tur sujati, ane dadi pangawit saluiring ane kaadakang olih Ida Sang Hyang Widi Wasa (Wahyu 3:14)

(o) Come to Jesus Christ, He is the living Stone that people rejected, but which God has chosen and highly honored (Peter2:4)

Tangkilja ring Ida Sang Penembahan, sane maraga batu urip sane kentungang antuk manusane satmaka tan paji, nanging kaselik tur kaluihang antuk Ida Sang Hyang Widi Wasa. (1 Petrus 2:4).

(p) Which flowed from the spiritual rock that followed them. That rock was Christ (I Corinthians 10:4).

Dane sareng same nginum saking batu rohani sane nyarengin dane. Batune punika tan lian, inggih punika Ida Sang Kristus ngraga. (1 Korintus 10:4).

(q) I am Jesus! And I am the one who sent my angel to tell all you these things for the churches. I am David's great descendant, and I am also the bright morning star (Revelation 22:16).

Ulun ane Yesus, suba ngutus malekat ulune buat nuturang sapari unduke ene makejang teken kita, buat sakancan pasamuane. Ulun sentanan Sang Prabu Daud, ulun bintang siang ane masunaran galang. (Wahyu 22:16)

(r) I am merely a rose from the land of Tiang punika walnya sakadi sehare ring Saron, Sharon, a lily from the Valley (Song Sekar leli sane wenten ring bongkal gununge. of Songs 2:1). (kidung geguritan 2:1).

(s) They killed the prophets who spoke Dane nyedayang para utusan Ida Sang Hyang Widi about the coming of the one who Wasa sane duke njuni sampun nartayang indik abbeys God (Act 7:52). pancing rauh parekan Idane Sane Sujati. (Pamargin Para Utusan 7:52).

(a)

SL

The Lord All-Powerful
TL

Ida Sang Hyang Widhi

Wasa Sane Maha Kuasa

The reference $I$ in the SL translated into Ulun in the TL is to Jehovah (Describe as "the LORD All-Powerful") Similar description of a supreme being as all-powerful is common in the other great religion. "Jehovah has promised that whatever He plans will happen just as He has said it would". The idea of an all-powerful being who can ensure His plans will happen just as He wants, nothing and no one will change them.

(b)

SL LORD
TL

Ratu Panembahan

Here the LORD is used to address Jehovah. God has spoken to him (Abraham). He simply answers "Here I am" in SL and in TL Inggih titiang, Ratu Panembahan means the LORD that I worship (respondent).

(c)
SL

Immanuel
TL

Imanuel 
"A Young woman", "a son" and "Immanuel" are the usual terms used when referring to the birth to the birth of Jesus. A young woman in another version of Bible used the term "a virgin" which is translated in the TL into anak doa genten, marry had not intercourse with anyone when she conceived Jesus (Hence "Virgin birth") 'a son' is the description of Jesus and "Immanuel" means "God with us was a name given to a male child. There are references in the Bible to the Messiah which one being called Immanuel.

The data above show the success of the foreignizing approach in creating an equivalent effect. Using this method, the translator is expected to preserve the foreign identity of the source text by seeking the "purely formal" replacement of one word or phrase in the SL by another in the TL. For this reason, the foreignizing approach is not commonly utilized.

Seeing the fact above the translator used the strategy of borrowing to keep the message equivalent.

(d)

\section{SL} King
TL

Sang Prabu

The use of King in this context is just another way of saying that the LORD (Jehovah) is the Jews' Supreme being. The speaker wants others to tell the word it will be a peaceful, and Jehovah will judge and decide matters fairly or justly (that was the mark of a good ruler). It is also a common usage in other main religions to place the Supreme being above man and to have him rule justly.

Based on the text above the term King in the SL is translated into Sang Prabu in the TL, the strategy of equivalence (by transferring the closest meaning) of the components that are exiting in the SL into the TL is applied by the translator.

(e)
SL

Our LORD
TL

Duh Ratu Sang Hyang Widi Wasa

The used of "Our LORD" here is simply another way of speaking to Jehovah. The speaker is thanking Jehovah for making the nation (The Jews) strong whether the speaker means strong as in economic strength (good harvest) or in war is not clear. Because of what Jehovah has done, The Jews are glad and celebrate their harvest. The two comparisons refer to the traditional celebrations held in every country for soldiers to loot a defeated city and divide among themselves what they had taken. LORD and King occur regularly in other religious writings (respondent).

(f)

SL
Wonderful Counsellor
Mighty God

Eternal Father

Prince of Peace
TL

Juru Pitutur Wicaksana

Ida Sang Hyang Widi

Wasa Sane Maha Kuasa

Sang Aji Sane Langgeng

Ratu Damene

Isaiah is predicting the coming of the Messiah, that arrival and just rule are constantly referred to throughout the Old Testament. The reference is to a son of the tribe or in present-day terms "family" and great care is taken in the New Testament to trace Jesus descent from King David, the names which $\mathrm{He}$ is given Wonderful Counselor, Mighty God, Eternal Father or Prince of Peace are simply titles given to Him (respondent).

Seeing the fact in the SL Wonderful counselor is translated into Juru pitutur Wicaksana, mighty God in the SL is translated into Ida Sang Hyang Widi Wasa Sane Maha keasa, Eternal Father is translated into Sang Aji sane Langgeng and the term Prince of peace in the SL is translated into Ratun Damene in the TL the translator tries to translate the message of the SL to similar meaning into the TL, so the strategy of equivalence is applied.

(g)

SL The LORD Almighty
TL

Ida Sang Hyang Widi

Wasa Sane Maha Kuasa

Many titles of forms of address for God has developed during the past 2000 years, today the trend appears in many cases to abandon the more formal "LORD God Almighty" or "LORD God of Hosts" approach and simply address God as God adding whatever adjective the worshipper wishes. "Loving God" is particularly popular of "God of Love". "God of All Grace" and one which described him as "God of All Emotions" all-encompassing diverse yet steadfast today, the form of address appears often depend on what context the worshipper is praying whether in need, giving thanks, in trust, in faith, in fear and so on.

The translator used the strategy of modulation to retain the message of the SL The LORD Almighty into the closest equivalence Ida Sang Hyang Widi Wasa sane Maha Kuasa as there are no such terms in the TL.

(h)
SL

Shepherd
TL

Sang Pangangon 
The term shepherd of Israel is a term used to address Jehovah, a poetic term for Him from a nation of sheep and goat herders, the "winged creatures" are angels who traditionally gather around the throne, while the speaker begs Him to listen to and grant his prayer.

The references to sheep parable many time, do ask Balinese Christian to accept the "Sheep" references? If Jesus instruction to "feed my sheep" is taken literally, then it simply means care for my people that is the Christian congregation.

Probably in these cases, the use of the English expression within quotes would be the best way to go, but in many other cases, a literal translation is probably not warranted.

Using whatever description rings true to those reading is surely better than asking them to struggle with the totally unfamiliar concept (respondent).

(i)

\section{SL}

Your Word

The Word

The Word
TL

Sabdan Palungguh I Ratu

Sabda

Sang Sabda

The Phrase the Word of God occurs nearly fifty times in the New Testament and is used without number by Christians in books, sermons, and ordinary speech.

It is dangerous to use any phrase or word in a different sense from the Bible. Doing so generally springs from a wrong understanding of spiritual truth, which it, in turn, perpetuates and reinforces, It cannot be afforded to adapt the meanings of words and phrases used in the Bible to suit our own traditions. It is pointless believing in the inspiration and authority of scripture and then using its words with meanings entirely different from their original.

It common parlance the phrase the Word of God or often simply the Word means to the Bible. This is standard terminology among almost all who believe in the inspiration and authority of the Bible.

In the Bible itself, the phrase the Word of God does not mean the Bible but has a different meaning. In this study, it will be explored the meaning and operation of the Word of God. After that, it is sought to rediscover the right place and use of the scriptures.

The nearest the Bible ever comes to calling itself the word God is in Matthew chapter 15, with an almost identical passage in Mark chapter 7. It is quoting in full:

Jesus said: "Why do you selfish transgress the commandment of God for the sake of your tradition? For God said, "Honour your father and mother", and He who speaks evil of father or mother, let him be put to death." But you say, "Whoever shall say to his father or mother," Anything of mine by which you might help has been given to God, "he is (allowed) not to honor his father or mother." And thus you have invalidated the Word of God for the sake of your tradition."

At first sight, it is construed the Word of God here as meaning the scripture. However, the examination refers specifically to what God actually said, his words to Moses for all Israel and the worlds, 'Honour your father and mother'. Jesus was not using the phrase as a general term for the scripture as the whole. This one verse there many passages where the Word of God cannot refer to the scriptures. For instance: "They spoke the word of God with boldness" (Acts 4: 31)," They preached the word of God in the synagogues of Judaea" (Acts 13: 5). "It was necessary for the word of God to be spoken to you first" (Acts 13:46),.." speak the word of God fearlessly" (Philippians 1:14), "the word of God is not bound" (Timothy 2:9), and above all, "The word became flesh and dwelt among us" (John $1: 14$ ) and "his name is called the word of God" (Revelation 19: 13).

In Acts 17:11, the word and the scriptures occur in the same verse: '... they received the word with all eagerness, daily examining the scriptures whether these things were so". The "word" here cannot possibly mean the "scriptures".

In the Old Testament Psalm 119:105 might appear to support the idea of referring to the scriptures as the word of God Nearly all its 176 verses which contain one of the following words: law, testimonies, ways, precepts, statutes, commandments, judgments, word, ordinances. This lends a little support to equating the "word" with law, testimonies, commandments, etc, but hardly enough to justify referring to the whole Bible as the word of God.

The Bible refers to itself as the scriptures, the holy scriptures, or in part the law or the prophet, but it does not call itself the "word of God" In its pages that phrase has a different meaning. The Bible does regard itself as verbally inspired by the Holy Spirit, and having absolute divine authority.

Much the greatest Word that God has ever spoken is Jesus. Jesus is the supreme manifestation of the word of God. The Apostle John began his gospel: "In the beginning was the Word, and the Word was with God, and the Word was God". Later in the same chapter, we read: "And the word became flesh and dwelt among us, and we beheld his glory, glory as of the only begotten from the Father, full of grace and truth. "Revelation 19: 13 gives Jesus the same title: "His name is called the Word of God". Hebrews 1:1 and 11:13 have the same implication: "God ... in 
these last days has spoken to us in his Son ... through whom also he made the world". "By faith, we understand that the world was prepared by the word of God".

Jesus is the supreme and central manifestation of the Word of God. All other manifestations of that word relate to him. The phrase the Word of God in Scripture is also used to describe anything that God said to anyone or through anyone. For example, "the word of the Lord came to Moses", "the word of God came to John in the wilderness". "The word of the Lord to Israel through Malachi" or "the words of Amos which he saw concerning Israel".

When God speaks, it is the word of God. In the Old Testament God spoke directly to the prophets. He spokes to others through them. He also spoke through events in the lives of individuals and the nation. This state of affairs continued essentially until Pentecost when the Spirit was poured out upon all flesh. The circle of those to whom he wants to speak directly is extended to all who believe. No longer is it only a few prophets and leaders, but it is the common man.

Many titles of forms used to address for LORD and Jesus which described Him as Amen, is a description of Christ and would be best translated accordingly. The last Adam, in the context of I Corinthians 15 44-46, could be interpreted as simply a physical body rising "at the last trump." The contest speaks of the physical body dying and the spiritual body rising on the last day.

The living stone, a metaphor should be read in the context of construction; the cornerstone was the one that gave the building strength. Hence Jesus was the "cornerstone" that the builders (the Jews) rejected, but which actually was the cornerstone needed. The "living stone" is Jesus as the founder of Christianity.

\section{Conclusions}

There are two conclusions that can be presented after the discussion on the proceeding field are as follows:

1) The terms of address are integrated into the text of the Old Testament (Bible) by applying the methodology of translations as introduced by Vinay and Darbelnett in Venuti (2000): Literal translation, transposition, equivalence, modulation, adaptation, borrowing (modification borrowing).

2) The terms of address related to behavior are the most frequent occurrence of terms of address are toward God as God reveals Himself to people.

\section{References}

Bassnett, S., \& English Association. (1997). Translating literature. Ds Brewer.

Braun, F., \& Schubert, K. (1988). When polite forms are impolite, or what politeness actually is. Terms of Address.

Problems of Patterns and Usage in Various Languages and Cultures. Berlin: Mouton de Gruyter, 45, 64.

Brown, R., \& Gilman, A. (1960). The pronouns of power and solidarity.

Hatim, B. A., \& Munday, J. (2004). Translation: An advanced resource book. Routledge.

Larson, M. L. (1984). Meaning-based translation: A guide to cross-language equivalence (Vol. 366). Lanham, MD: University Press of America.

Nida, E. A. (1964). Toward a science of translation. Leiden: Brill.

Subiyanto, P. (2016). The impact of transposition on grammatical metaphor a study of translation from the perspective of SFL theory. International Journal of Linguistics, Literature, and Culture, 2(3), 117-123.

Suryasa, I. W., Sudipa, I. N., Puspani, I. A. M., \& Netra, I. M. (2019). Translation of Krsna text and ideology. International Journal of Social Sciences and Humanities, 3(1), 36-47. https://doi.org/10.29332/ijssh.v3n1.251

Venuti, L. (2012). The translation studies reader. Routledge.

Venuti, L. (2017). The translator's invisibility: A history of translation. Routledge. https://doi.org/10.4324/9781315098746

Wu, C. F. J. (1986). Jackknife, bootstrap and other resampling methods in regression analysis. the Annals of Statistics, 14(4), 1261-1295.

\section{Data Sources}

Lembaga Alkitab Indonesia 1990. Cakepan Suci. Bogor: Lembaga Alkitab Indonesia

The British \& Foreign Bible Society. 1978. Good News Bible: Today's English Version. London 